\title{
Iraqi Super Grid Network State Estimation Using PSO Technique
}

https://doi.org/10.32792/utg/utj/vol10/2/2

\author{
Assist. Prof. Dr. Afaneen A. Abood \\ Department of Electrical Engineering \\ Engineering \\ University of Technology \\ Baghdad-Iraq
}

afaneenalkazragy@yahoo.com

\author{
Anmar Jasim Hameed \\ Department of Electrical \\ University of Technology \\ Baghdad -Iraq \\ an_ch2009@yahoo.com
}

\begin{abstract}
Power System State Estimation (PSSE) became a main subject in the operation of power systems through its important role in ensuring the secure and economical operation of the power system. In this work, two approaches were proposed and implemented in order to search for the optimal solution of state estimation in power systems, the first approach used a conventional state estimation program based on Weighted Least Square (WLS) method, and the second one used an intelligent technique based on Particle Swarm Optimization (PSO). All programs were implemented using MATLAB and developed to solve the state estimation problem of the Iraqi Super Grid network $(400 \mathrm{kV})$. The results showed that the PSO is more accurate and it convergence close to the optimal solution.
\end{abstract}

Keywords: Power System State Estimation (PSSE), Particle Swarm Optimization (PSO). Weighted Least Square (WLS)

\section{تخمين حالة منظومة الثبكة العر اقية استناداً الى تقتية امثلية الحثد الجزيئي}

$$
\begin{aligned}
& \text { يُعتبر تخمين حالة منظومات القدرة الكهربائية من الأمور المهمة في تشغيل منظومات القدرة وخصوصا في حالة } \\
& \text { الحمل الزائد على شبكة الطاقة الكهربائية من خلال دوره في ضمان تشغيل أكثر افتصادية و أمان. نم اعداد } \\
& \text { و اقتراح برنامجين للتغلب على سلبيات الطرق التقليدية وللبحث عن الحل الأمثل في تخمين حالة منظومات } \\
& \text { القدرة, البرنامج الأول هو برنامج تقليدي لتخمين حالة القدرة بستخدم طريقة التربيعات الموزونة (WLS), }
\end{aligned}
$$

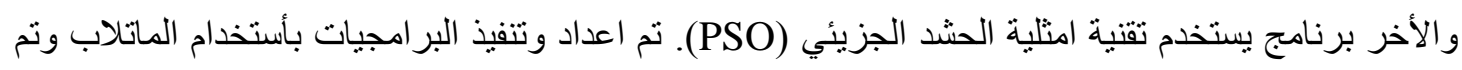

$$
\begin{aligned}
& \text { تتظويره لحل مشكلة تخمين حالة الثبكة العر اقية. كما أظهرت نتائج طريقة تقنية امثلية الحشد الجزيئي (PSO) }
\end{aligned}
$$

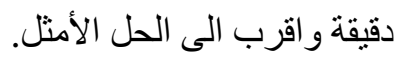




\section{Introduction}

7 he problem of monitoring the power flows and voltages on a transmission system is very important in maintaining system security, By simply checking each 1 measured value against its limit, the power system operators can tell where problems exist in the transmission system and can take corrective actions to relieve overloaded lines or out of limit voltages [1,2].

Power system state estimation is the process in which a best estimate of the state of the system is obtained based on a set of real-time system measurements for a predetermined system model. It plays an important role in modern Energy Management Systems (EMS) by providing a complete, consistent, accurate and reliable database as an input to other key functions of the EMS system, such as Contingency Analysis, Optimal Power Flow (OPF), Security Monitoring, Automatic Voltage Control (AGC) and Economic Dispatch (ED),...etc. [3].

Studies of Power System State Estimation (PSSE) have been attempted by many researchers and papers. C. Venkatesh [4] presented an Interline power flow controller based on the conventional power system state estimation model, Hee-Myung [5] considered a binary PSO for identifying multiple bad data in the framework of the least squares state estimation, Jiaxiong [6] proposed state estimation method based on the extended weighted least squares (WLS) method for considering both measurement errors and model inaccuracy, Efthymios' s work [7] presents an ANN-based approach to pseudo measurement modeling for distribution system state estimation (DSSE). The proposed methodology uses load profiles and offline load flow analysis or historical data to train two ANNs, Ab. Halim[8] presented Weight least Square (WLS) method based on Particle Swarm Optimization (PSO) to identify the optimal measurement placement of power system state estimation, D.H. Tungadio [9] proposed the PSO algorithm for the power system state estimation (PSSE) problem. Two different approaches have been used to model the objective function of PSSE, that is, weighted least squares (WLS) and weighted absolute value (IRLS).

In this work two approaches were used and tested on the Iraqi Super Grid, those are: the conventional Weighted Least Square (WLS) method and the Particle Swarm Optimization (PSO) technique.

\section{The Weighted Least Square (WLS) mathematical representation}

Due to noise or random error, the true value of any physical quantity is not known; hence, a suitable procedure has to be followed to calculate the best estimate of the unknown quantity [1]. The method of least squares is often used to "best fit" measured data relating to two or more quantities.

The true but unknown measurement vector $[z]$ is related to the true but unknown state vector $[x]$ and the error vector $[e]$ by the relation $[10]$ :

$$
[z]=\left[z_{(x)}\right]+[e]
$$


Web Site: https://jutq.utq.edu.iq/index.php/main Email: journal@jutq.utq.edu.iq

$$
z=\left[\begin{array}{c}
z_{1} \\
z_{2} \\
\cdot \\
\cdot \\
\cdot \\
z_{m}
\end{array}\right]=\left[\begin{array}{c}
h_{1}\left(x_{1}, x_{2}, \ldots . ., x_{n}\right) \\
h_{2}\left(x_{1}, x_{2}, \ldots . ., x_{n}\right) \\
\cdot \\
\cdot \\
\cdot \\
h_{m}\left(x_{1}, x_{2}, \ldots ., x_{n}\right)
\end{array}\right]=\left[\begin{array}{c}
e_{1} \\
e_{2} \\
\cdot \\
\cdot \\
\cdot \\
e_{m}
\end{array}\right]=h(x)+e
$$

Where:

[z] : the measurements vector.

$h^{T}=\left[h_{1}(x), h_{2}(x), \ldots, h_{m}(x)\right]$

$\mathrm{h}_{1}(\mathrm{x})$ : The nonlinear function relating measurement $\mathrm{z}_{\mathrm{i}}$ to the state vector $\mathrm{x}$.

$\mathrm{x}^{\mathrm{T}}=\left[\mathrm{x}_{1}, \mathrm{x}_{2}, \ldots, \mathrm{x}_{\mathrm{m}}\right]$, the system state vector.

$\mathrm{e}^{\mathrm{T}}=\left[\mathrm{e}_{1}, \mathrm{e}_{2}, \ldots, \mathrm{e}_{\mathrm{m}}\right]$, the vector of measurement errors.

$\mathrm{m}$ : no. of measurements

$\mathrm{n}$ : no. of state variables

$$
\mathrm{E}\left(\mathrm{e}_{\mathrm{i}}\right)=0, \quad \mathrm{i}=1,2,3, \ldots, m .
$$

Measurement errors are independent, i.e. $E\left[\mathrm{e}_{\mathrm{i}} \mathrm{e}_{\mathrm{j}}\right]=0$ Hence,

$$
\operatorname{cov}(e)=E\left[e \cdot e^{T}\right]=R=\left[\begin{array}{cccc}
\sigma_{1}^{2} & & & \\
& & & \\
& \sigma_{2}^{2} & & \\
& & \cdot & \\
& & & \\
& & & \sigma_{m}^{2}
\end{array}\right]
$$

The standard deviation $\sigma_{i}$ of each measurement, $i$ is calculated to reflect the expected accuracy of the corresponding meter used .The actual error $[\mathrm{e}]$ is given by:

$$
[e]=[z]-[h(x)]
$$

The actual (true) error cannot he determined because the true state vector value $[\mathrm{x}]$ is unknown, but their estimates can be calculated.

The estimated error is:

$$
\begin{aligned}
& {[\hat{e}]=[z]-[\hat{z}]} \\
& {[\hat{e}]=[z]-[h(\hat{x})]}
\end{aligned}
$$

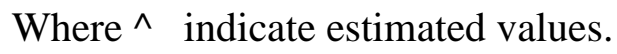

The criterion for calculating the best estimates of state vector $[\hat{\mathrm{x}}]^{\mathrm{T}}$ is to minimize the sum of the squares of the errors. To ensure that measurements from meters of known accuracy are treated more famously than less accurate measurements, each 
term in the sum of squares is multiplied by weight factor w. The weight factors are chosen as a reciprocal of the corresponding variance $\delta_{\mathrm{i}}^{2}$.

The WLS formulation can be expressed with the following minimization function, which is the sum of the squared normalized residuals

$J(\hat{x})=\sum_{j=}^{m} w_{i} e_{i}^{2}$

Where:

$w_{i}=\frac{1}{\delta_{i i}^{2}}=\frac{1}{R_{i i}}$ i s the weighting factor

$J(\hat{x})=\sum_{i=1}^{m} \frac{\left(z_{i}-h_{i}(\hat{x})\right)^{2}}{R_{i i}}$

Can be expressed Equation (9) in matrix form as:

$J(\hat{x})=[z-h(\hat{x})]^{T} R^{-1}[z-h(\hat{x})]$

At the minimum, the first order optimality conditions will have to be satisfied. These can be expressed in compact form as follows:

$\mathrm{g}(\mathrm{x})=\frac{\partial \mathrm{J}(\mathrm{x})}{\partial \mathrm{x}}=\mathrm{H}^{\mathrm{T}}(\mathrm{x}) \mathrm{R}^{-1}[\mathrm{z}-\mathrm{h}(\mathrm{x})]=0$

Where : $H(x)=\left[\frac{\partial h(x)}{\partial x}\right]$

Expanding the nonlinear function $g(x)$ into its Taylor series around the state vector $x^{k}$ yields:

$g(x)=g\left(x^{k}\right)+G\left(x^{k}\right)\left(x-x^{k}\right)+\ldots=0$

Neglecting the higher order terms leads to an iterative solution scheme known as the Gauss-Newton method as shown below:

$x^{k+1}=x^{k}-\left[G\left(x^{k}\right)\right]^{-1} \cdot g\left(x^{k}\right)$

Where: $k$ is the iteration index.

$x^{k}$ Is the solution vector at iteration $k$.

$G\left(x^{k}\right)=\frac{\partial g\left(x^{k}\right)}{\partial x}=\mathrm{H}^{\mathrm{T}}\left(\mathrm{x}^{\mathrm{k}}\right) \mathrm{R}^{-1}\left[\mathrm{z}-\mathrm{h}\left(\mathrm{x}^{\mathrm{k}}\right)\right]$

$g\left(x^{k}\right)=-\mathrm{H}^{\mathrm{T}}\left(\mathrm{x}^{\mathrm{k}}\right) \mathrm{R}^{-1}\left[\mathrm{z}-\mathrm{h}\left(\mathrm{x}^{\mathrm{k}}\right)\right]$

$G(x)$ is called the gain matrix. It is sparse, positive definite and symmetric provided that the system is fully observable. The matrix $G(x)$ is typically not inverted, 
but instead it is decomposed into its triangular factors and the following sparse linear set of equations are solved using forward/ back substitution at each iteration,

\section{Weighted Least Squares (WLS) Algorithm [11]}

Weighted Least Squares (WLS) state estimation involves the iterative solution of the normal equations. An initial guess has to be made for the state vector $x^{0}$. As in the case of the power flow solution, this guess typically corresponds to the flat voltage profile, where all bus voltages are assumed to be 1.0 per unit and in phase with each other.

The iterative solution algorithm for WLS state estimation problem can be outlined as follows:

1. Begin the iteration by setting the iteration index $\mathrm{k}=0$, then, set flat start values 1 and 0 to bus voltage magnitudes and bus phase angles respectively. Finally, $\varepsilon$ is set to a certain value.

2. Calculate, $h\left(x^{k}\right)$.

3. Calculate the gain matrix $G\left(x^{k}\right)$ and Jacobin matrix $H\left(x^{k}\right)$

4. Decompose $G\left(x^{k}\right)$ and solve for $\Delta x^{k}$.

5. Test for convergence, $\max \left|\Delta x^{k}\right| \leq \varepsilon$.

6. If max $\left|\Delta x^{k}\right|>\varepsilon$, update $x^{k+1}=x^{k}+\Delta x^{k}, k=k+1$, and go to step2. Else, stop.

The algorithm flowchart is shown in the Appendix.

\section{Particle Swarm Optimization (PSO)}

Particle Swarm Optimization (PSO) is based on the behavior of a colony or swarm of insects, such as ants, termites, bees, and wasps; a flock of birds; or a school of fish. The particle swarm optimization algorithm mimics the behavior of these social organisms [12]. Each particle is assumed to have two characteristics: a position and a velocity. Each particle wanders around in the design space and remembers the best position (in terms of the food source or objective function value) it has discovered. The particles communicate information or good positions to each other and adjust their individual positions and velocities based on the information received on the good positions [13]

Basic algorithm as proposed by Kennedy and Eberhart (in 1995), introduced to calculate the velocity and position of each particle and it is used to find the optimal solution

Where

$x_{j}^{i}$ : Particle position

$v_{j}^{i}$ : Particle velocity

$p_{j}^{i}$ : Best position found by jth particle (personal best)

$p_{j}^{g}$ : Best position found by swarm (global best, best of personal bests) 
Position of individual particles updated as follows:

$x_{j+1}^{i}=x_{j}^{i}+v_{j+1}^{i} \quad j=1, \ldots, n$

With the velocity calculated as follows:

$v_{j+1}^{i}=v_{j}^{i}+c_{1} r_{1}\left(p_{j}^{i}-x_{j}^{i}\right)+c_{2} r_{2}\left(p_{j}^{g}-x_{j}^{i}\right) \quad j=1, \ldots, n$

Where $c_{1}$ and $c_{2}$ are the cognitive (individual) and social (group) learning rates, respectively, and $r_{1}$ and $r_{2}$ are uniformly distributed random numbers in the range 0 and 1 . The parameters $c_{1}$ and $c_{2}$ denote the relative importance of the memory (position) of the particle itself to the memory (position) of the swarm. The values of $c_{1}$ and $c_{2}$ are usually assumed to be 2 .

The particle velocities build up too fast and the minimum of the objective function is skipped. Hence an inertia term, w, is added to reduce the velocity. Usually, the value of $\mathrm{w}$ is assumed to vary linearly from 0.9 to 0.4 as the iterative process progresses. The velocity of the jth particle, with the inertia term, is assumed as:

$v_{j+1}^{i}=w_{i} v_{j}^{i}+c_{1} r_{1}\left(p_{j}^{i}-x_{j}^{i}\right)+c_{2} r_{2}\left(p_{j}^{g}-x_{j}^{i}\right) \quad j=1, \ldots, n$

To achieve a balance between global and local exploration to speed up convergence to the true optimum, an inertia weight whose value decreases linearly with the iteration number has been used as:

$\mathrm{w}_{\mathrm{i}}=\mathrm{w}_{\max }-\left(\frac{\mathrm{w}_{\max }-\mathrm{w}_{\min }}{\mathrm{imax}}\right) * \mathrm{i}$

Where $\mathrm{w}_{\max }$ and $\mathrm{w}_{\min }$ are the initial and final values of the inertia weight, respectively, and imax is the maximum number of iterations used in PSO $[12,13]$.

\section{Power System State Estimation using PSO}

The non - linear equations relating the measurements vector $[z]$ and the true state variable $[x]$ :

$$
[z]=[h(x)]+[e]
$$

Because of noise, the true values of the state vector $x$ are never known, and the best possible estimates of the state vector is calculated based on Particle Swarm Optimization method (PSO). The usual state variables are the voltage magnitude and angle, while the measurements are the real and reactive power flows, node injections and voltage magnitudes.

The objective function of the state estimation is the same as that of conventional state estimation as follows: The PSO estimator will minimize the objective function $J[\hat{x}]$ given by Equation (10) and rewritten as follows:

$$
J[\hat{x}]=[z-h(\hat{x})]^{T} R^{-1}[z-h(\hat{x})]
$$

The PSO Algorithm can be described as follows [15]:

A) State variable: The bus voltage phase angles and magnitudes are considered to be state variables. The state variable particles are: $\theta_{2}, \theta_{3} \ldots \theta_{\mathrm{n}}, \mathrm{V}_{1}, \mathrm{~V}_{2} \ldots \mathrm{V}_{\mathrm{n}}$ 


\section{University of Thi-Qar Journal Vol.10 No.2 June 2015}

Web Site: https://jutq.utq.edu.iq/index.php/main Email: journal@jutq.utq.edu.iq

B) Proposed State estimation algorithm: The following algorithm is used for the state estimation.

Step 1 Input data: Network configuration, line impedance - contracted load value measurement data

Step 2 Set calculation conditions

i. Calculation of initial values of state variables: Using measurement data and state variables, initial load-flow calculation is performed.

ii. Set upper and lower bounds of state variables: Using the results of initial load-flow calculation, the upper and lower bounds of each state variable can be calculated.

Step 3 State estimation: Use PSO algorithm

Step 4 Converge criteria: The algorithm stops looking for a solution if the maximum of a variation of the state variable $\Delta \mathrm{x}$, is smaller than 0.0001 and the iterations have reached the maximum number of iterations specified.

Step 5 Bad data detection and identification

i. Detection: The method used for bad data detection is the Chi-squares test.

ii. Identification: Upon detection of bad data in the measurement set, their identification can be accomplished by further processing of the residuals, namely the Largest Normalized Residual (LNR) test [14, 15].

The flowchart of the PSO program is shown in the Appendix.

\section{Simulation Results}

The aim of this work is solving the State Estimation problem of the Iraqi Super Grid Network (400kv). To Do so, Two methods were used those are, the conventional (WLS) estimator and bad data detection and identification algorithms and the Particle Swarm Optimization (PSO) state estimation algorithm.

The Iraqi Super Grid network contains (29) bus bars, (16) generating plant and (38) transmission lines. The measured data for Iraqi network was taken from the Iraqi National Dispatch Center. The components of the Iraqi power system were modeled using MATLAB programming language.

In order to evaluate the performance of the state estimator, a base case or a reference case of the system is required. Hence, the system is solved using the power flow using Newton Raphson method which was assumed to be the actual or true power flow values of this system.

The effectiveness of the proposed approach is demonstrated. Additionally, the performance of the proposed estimator with the conventional one is compared in terms of accuracy. The Mean Square Error (MSE) was used to clarify the accuracy of the algorithms.

Tables (1) and (2) show a comparison between the actual and the estimated values variables (bus voltage magnitude and buses voltage angle) using both algorithms with their MSE error.

The estimated values are compared against the actual values using a bar chart. Figure (1) and (2) show a plot of state variables (buses voltage magnitudes and buses voltage angles) respectively.

While the estimated values of the real/reactive power flow and real/reactive power injection illustrated in Tables (3) - (6) respectively.

The estimated (both real and reactive) bus power injection and line power flows values are also plotted against the actual values, for both methods (WLS and PSO), as shown in Figures (4) - (7). 
University of Thi-Qar Journal Vol.10 No.2 June 2015

Web Site: https://jutq.utq.edu.iq/index.php/main Email: journal@jutq.utq.edu.iq

Table (1): Actual and estimated Voltage magnitudes

\begin{tabular}{|l|l|l|l|l|l|l|}
\hline $\begin{array}{l}\text { Bus } \\
\text { No. }\end{array}$ & $\begin{array}{l}\text { Bus } \\
\text { Name }\end{array}$ & $\begin{array}{l}\text { Voltage } \\
\text { Actual } \\
\text { (P.u) }\end{array}$ & $\begin{array}{l}\text { Voltage } \\
\text { (WLS) } \\
\text { (P.u) }\end{array}$ & $\begin{array}{l}\text { Voltage } \\
\text { (PSO) } \\
\text { (P.u) }\end{array}$ & $\begin{array}{l}\text { Abs. error } \\
\text { (WLS) }\end{array}$ & $\begin{array}{l}\text { Abs. error } \\
\text { (PSO) }\end{array}$ \\
\hline 1 & BAJP & 0.952 & 0.8749 & 0.9196 & 0.0771 & 0.0324 \\
\hline 2 & MMDH & 0.9656 & 0.8688 & 0.9242 & 0.0968 & 0.0414 \\
\hline 3 & GNENW & 0.9489 & 0.8628 & 0.9104 & 0.0861 & 0.0385 \\
\hline 4 & MSL4 & 0.9478 & 0.8591 & 0.9167 & 0.0887 & 0.0311 \\
\hline 5 & BAJG & 0.9522 & 0.8750 & 0.9198 & 0.0772 & 0.0324 \\
\hline 6 & KAK4 & 0.9493 & 0.8810 & 0.9305 & 0.0683 & 0.0188 \\
\hline 7 & BGW4 & 0.8988 & 0.8481 & 0.8924 & 0.0507 & 0.0064 \\
\hline 8 & BGS4 & 0.9039 & 0.8613 & 0.9060 & 0.0426 & 0.0021 \\
\hline 9 & BGE4 & 0.8989 & 0.8416 & 0.8906 & 0.0573 & 0.0083 \\
\hline 10 & BGN4 & 0.8983 & 0.8403 & 0.8899 & 0.0580 & 0.0084 \\
\hline 11 & QDSG & 0.9001 & 0.8414 & 0.8907 & 0.0587 & 0.0094 \\
\hline 12 & AMN4 & 0.8978 & 0.8404 & 0.8890 & 0.0574 & 0.0088 \\
\hline 13 & BGC4 & 0.8923 & 0.8419 & 0.8862 & 0.0504 & 0.0061 \\
\hline 14 & DAL4 & 0.929 & 0.8419 & 0.8897 & 0.0871 & 0.0393 \\
\hline 15 & KUT4 & 0.904 & 0.8338 & 0.9087 & 0.0702 & 0.0047 \\
\hline 16 & KUTP & 0.9103 & 0.8393 & 0.9013 & 0.0710 & 0.0090 \\
\hline 17 & HDTH & 0.9457 & 0.9029 & 0.9457 & 0.0428 & 0 \\
\hline 18 & QIM4 & 0.9502 & 0.8783 & 0.9220 & 0.0719 & 0.0282 \\
\hline 19 & MUSP & 0.9146 & 0.8694 & 0.9087 & 0.0452 & 0.0059 \\
\hline 20 & MUSG & 0.9144 & 0.8671 & 0.9064 & 0.0473 & 0.0080 \\
\hline 21 & BAB4 & 0.9173 & 0.8738 & 0.9095 & 0.0435 & 0.0078 \\
\hline 22 & GKHER & 0.935 & 0.9309 & 0.9300 & 0.0041 & 0.0043 \\
\hline 23 & KDS4 & 0.8971 & 0.8686 & 0.9813 & 0.0285 & 0.0842 \\
\hline 24 & NSRP & 0.8982 & 0.9064 & 0.9804 & 0.0082 & 0.0822 \\
\hline 25 & AMR4 & 0.9029 & 0.9312 & 0.9816 & 0.0283 & 0.0787 \\
\hline 26 & HRTP & 0.8971 & 0.9832 & 1.0041 & 08610. & 0.1070 \\
\hline 27 & KAZG & 0.8906 & 0.9421 & 1.0004 & 0.0515 & 0.1098 \\
\hline 28 & RMULG & 0.8978 & 0.9919 & 0.9997 & 0.1012 & 0.1019 \\
\hline 29 & BSR4 & 0.919 & 0.8921 & 1.0001 & 0.0269 & 0.0811 \\
\hline MSE & & & & & 0.0092 & 0.0030 \\
\hline & & & & & & \\
\hline
\end{tabular}


University of Thi-Qar Journal Vol.10 No.2 June 2015

Web Site: https://jutq.utq.edu.iq/index.php/main Email: journal@jutq.utq.edu.iq

Table (2): Actual and estimated Bus angles

\begin{tabular}{|c|c|c|c|c|c|c|}
\hline $\begin{array}{l}\text { Bus } \\
\text { No. }\end{array}$ & $\begin{array}{l}\text { Bus } \\
\text { Name }\end{array}$ & $\begin{array}{l}\text { Angle } \\
\text { Actual } \\
\text { (rad.) }\end{array}$ & $\begin{array}{l}\text { Angle } \\
\text { (WLS) } \\
\text { (rad.) }\end{array}$ & $\begin{array}{l}\text { Angle } \\
\text { (PSO) } \\
\text { (rad.) }\end{array}$ & $\begin{array}{l}\text { Abs. error } \\
\text { (WLS) }\end{array}$ & $\begin{array}{l}\text { Abs. error } \\
\text { (PSO) }\end{array}$ \\
\hline 1 & BAJP & 0 & 0 & 0 & 0 & 0 \\
\hline 2 & MMDH & -0.4709 & -0.4075 & -0.4597 & 0.0634 & 0.0112 \\
\hline 3 & GNENW & -0.4950 & -0.4470 & -0.4699 & 0.0480 & 0.0251 \\
\hline 4 & MSL4 & -0.4946 & -0.4584 & -0.4772 & 0.0362 & 0.0174 \\
\hline 5 & BAJG & -0.4615 & -0.4218 & -0.4439 & 0.0397 & 0.0176 \\
\hline 6 & KAK4 & -0.4585 & -0.4032 & -0.4278 & 0.0553 & 0.0307 \\
\hline 7 & BGW4 & -0.4576 & -0.3998 & -0.4190 & 0.0578 & 0.0386 \\
\hline 8 & BGS4 & -0.3725 & -0.3174 & -0.3332 & 0.0551 & 0.0393 \\
\hline 9 & BGE4 & -0.4046 & -0.3592 & -0.3634 & 0.0454 & 0.0412 \\
\hline 10 & BGN4 & -0.4156 & -0.3670 & -0.3741 & 0.0486 & 0.0415 \\
\hline 11 & QDSG & -0.4107 & -0.3624 & -0.3829 & 0.0483 & 0.0278 \\
\hline 12 & AMN4 & -0.3829 & -0.3567 & -0.3522 & 0.0262 & 0.0307 \\
\hline 13 & BGC4 & -0.4327 & -0.4032 & -0.4109 & 0.0295 & 0.0218 \\
\hline 14 & DAL4 & -0.4492 & -0.4045 & -0.4312 & 0.0447 & 0.0180 \\
\hline 15 & KUT4 & -0.2754 & -0.2332 & -0.2322 & 0.0422 & 0.0432 \\
\hline 16 & KUTP & -0.2676 & -0.2183 & -0.2211 & 0.0493 & 0.0465 \\
\hline 17 & HDTH & -0.4814 & -0.4376 & -0.4693 & 0.0438 & 0.0121 \\
\hline 18 & QIM4 & -0.5072 & -0.4731 & -0.4880 & 0.0341 & 0.0192 \\
\hline 19 & MUSP & -0.3252 & -0.3012 & -0.3100 & 0.0240 & 0.0152 \\
\hline 20 & MUSG & -0.3283 & -0.2832 & -0.2809 & 0.0451 & 0.0474 \\
\hline 21 & BAB4 & -0.3101 & -0.2480 & -0.2532 & 0.0621 & 0.0569 \\
\hline 22 & GKHER & -0.2649 & -0.1897 & -0.1996 & 0.0752 & 0.0653 \\
\hline 23 & KDS4 & -0.3164 & -0.2670 & -0.2752 & 0.0494 & 0.0412 \\
\hline 24 & NSRP & -0.2618 & -0.2095 & -0.2097 & 0.0523 & 0.0521 \\
\hline 25 & AMR4 & -0.2180 & -0.1841 & -0.1807 & 0.0339 & 0.0373 \\
\hline 26 & HRTP & -0.1763 & -0.1184 & -0.1380 & 0.0579 & 0.0383 \\
\hline 27 & KAZG & -0.1815 & -0.14085 & -0.1463 & 0.0406 & 0.0352 \\
\hline 28 & RMULG & -0.2063 & -0.1832 & -0.1924 & 0.0231 & 0.0139 \\
\hline 29 & BSR4 & -0.2862 & -0.2259 & -0.2291 & 0.0603 & 0.0571 \\
\hline \multicolumn{2}{|l|}{ MSE } & & & & 0.0021 & 0.0013 \\
\hline
\end{tabular}




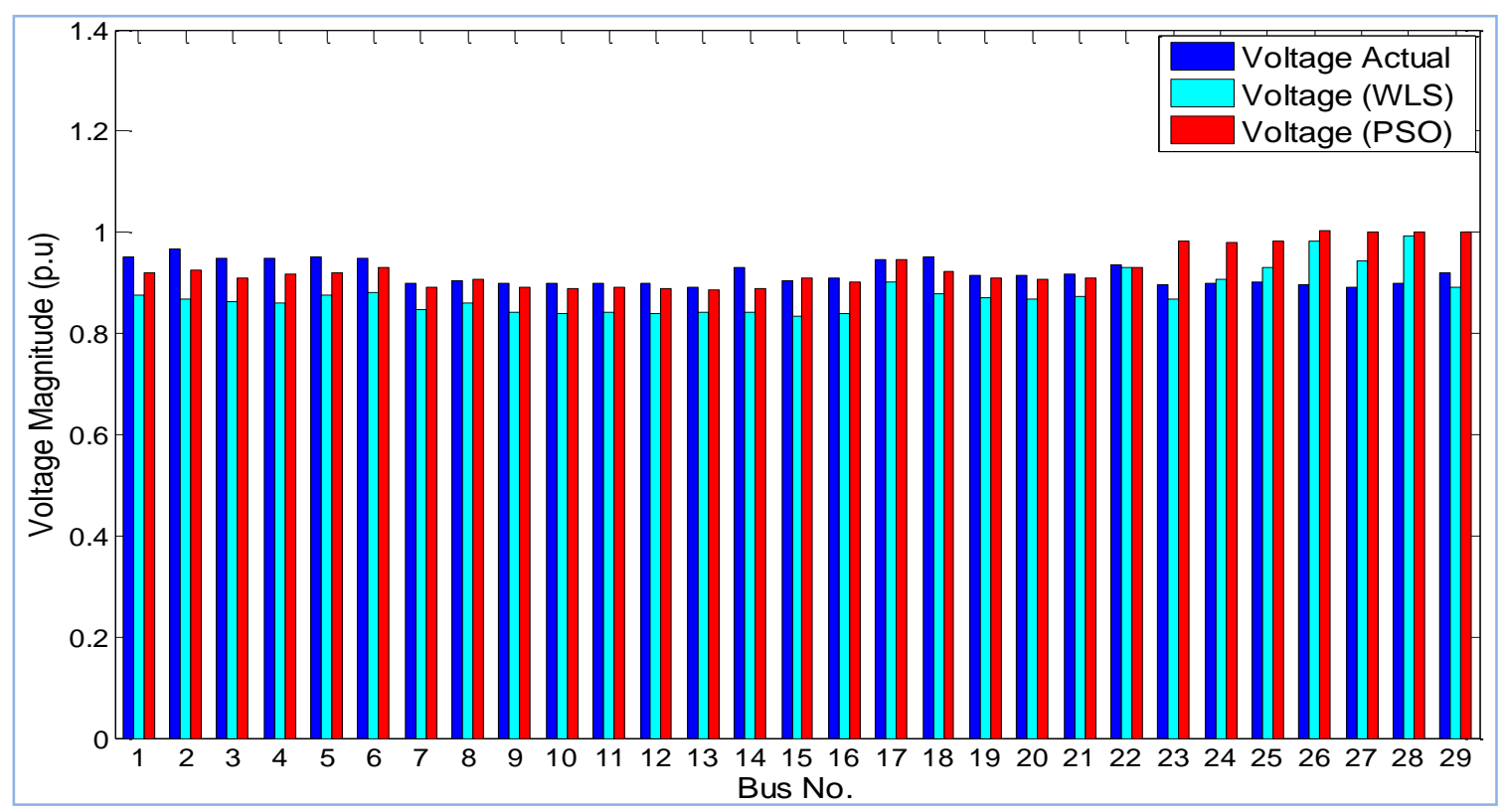

Figure (1): Comparison between actual and estimated values of the bus voltage magnitude

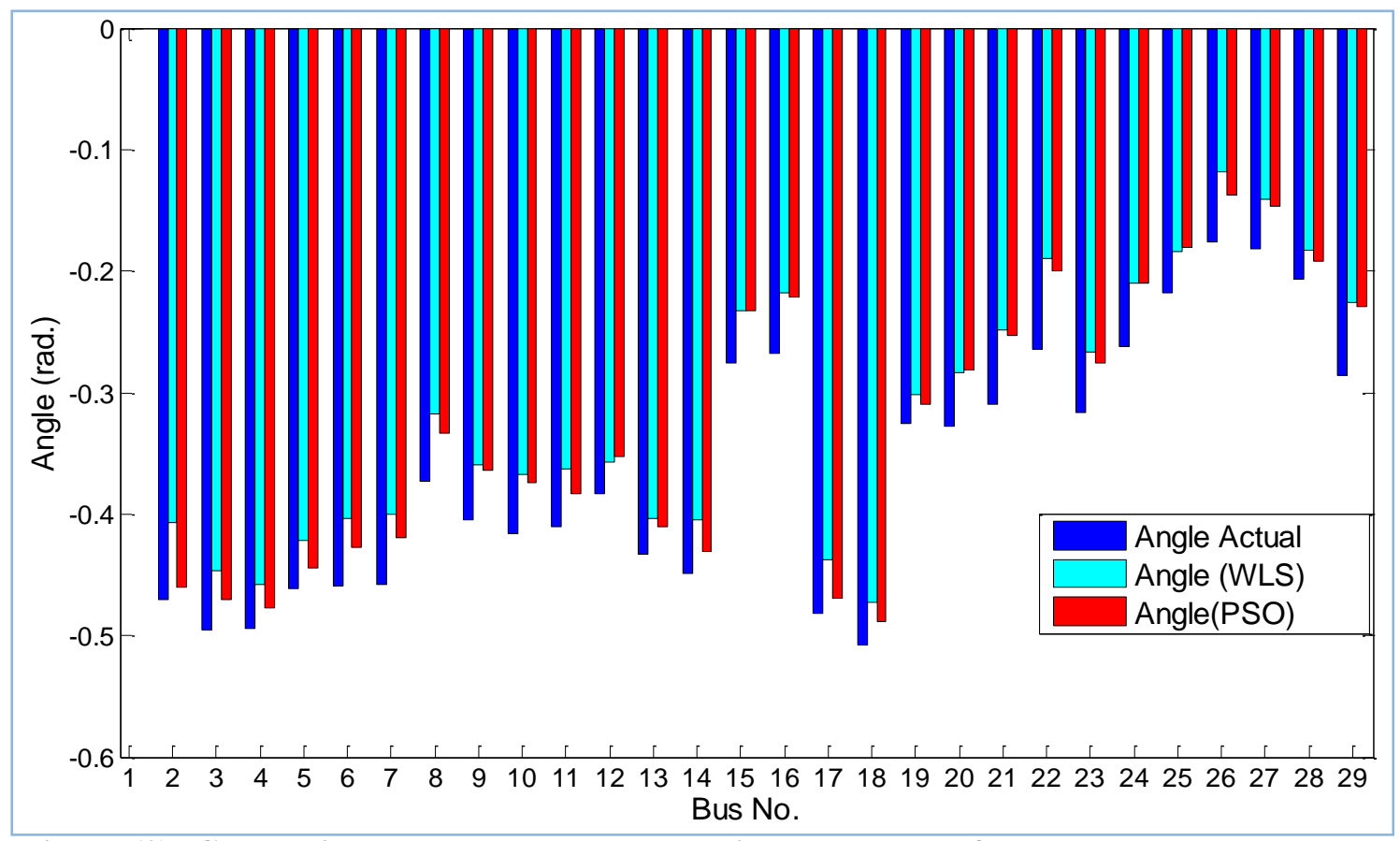

Figure (2): Comparison between actual and estimated values of the bus phase angle 
University of Thi-Qar Journal Vol.10 No.2 June 2015

Web Site: https://jutq.utq.edu.iq/index.php/main Email: journal@jutq.utq.edu.iq

Table (3): Actual and estimated active bus power injection

\begin{tabular}{|l|l|l|l|l|l|l|}
\hline $\begin{array}{l}\text { Bus } \\
\text { No. }\end{array}$ & $\begin{array}{l}\text { Bus } \\
\text { Name }\end{array}$ & $\begin{array}{l}\text { P Actual } \\
\text { (P.u) }\end{array}$ & $\begin{array}{l}\text { P estimation } \\
\text { (WLS) } \\
(\text { P.u })\end{array}$ & $\begin{array}{l}\text { P estimation } \\
\text { (PSO) } \\
\text { (P.u) }\end{array}$ & $\begin{array}{l}\text { Abs. error } \\
\text { (WLS) }\end{array}$ & $\begin{array}{l}\text { Abs. error } \\
\text { (PSO) }\end{array}$ \\
\hline 3 & GNENW & -0.9930 & -0.9428 & -0.9498 & 0.0502 & 0.0432 \\
\hline 4 & MSL4 & -4.5420 & -4.3229 & -4.4039 & 0.2191 & 0.1381 \\
\hline 6 & KRK4 & -2.5000 & -2.3995 & -2.4280 & 0.1005 & 0.0720 \\
\hline 8 & BGS4 & -1.5010 & -1.4168 & -1.4189 & 0.0842 & 0.0821 \\
\hline 9 & BGE4 & -0.0340 & -0.0220 & -0.0242 & 0.0120 & 0.0098 \\
\hline 10 & BGN4 & -4.5380 & -4.2563 & -4.3625 & 0.2817 & 0.1755 \\
\hline 12 & AMN4 & -2.2550 & -2.2065 & -2.2121 & 0.0485 & 0.0429 \\
\hline 13 & BGC4 & -2.1610 & -2.0050 & -2.0931 & 0.1560 & 0.0679 \\
\hline 15 & KUT4 & -1.7640 & -1.5027 & -1.5061 & 0.2613 & 0.2579 \\
\hline 16 & KUTP & -3.7340 & -3.8795 & -3.9632 & 0.1455 & 0.2292 \\
\hline 17 & HDTH & -0.3970 & -0.3135 & -0.3329 & 0.0835 & 0.0641 \\
\hline 20 & MUSG & 1.6000 & 1.4532 & 11.498 & 0.1468 & 0.1020 \\
\hline 21 & BAB4 & -1.2830 & -1.3931 & -1.3689 & 0.1101 & 0.0859 \\
\hline 22 & GKHER & 5.1000 & 5.3214 & 5.4030 & 0.2214 & 0.3030 \\
\hline 23 & KDS4 & -2.5270 & -2.3429 & -2.4528 & 0.1841 & 0.0742 \\
\hline 25 & AMR4 & 0.1780 & 0.2002 & 0.0212 & 0.0222 & 0.1568 \\
\hline 26 & HRTP & 1.6920 & 1.8645 & 1.8646 & 0.1725 & 0.1726 \\
\hline 28 & RMULG & 0 & -0.0588 & -0.0598 & 0.0588 & 0.0598 \\
\hline
\end{tabular}

Table (4): Actual and estimated reactive bus power injection

\begin{tabular}{|l|l|l|l|l|l|l|}
\hline $\begin{array}{l}\text { Bus } \\
\text { No. }\end{array}$ & $\begin{array}{l}\text { Bus } \\
\text { Name }\end{array}$ & $\begin{array}{l}\text { Q Actual } \\
\text { (P.u) }\end{array}$ & $\begin{array}{l}\text { Q } \\
\text { estimation } \\
\text { (WLS) } \\
\text { (P.u) }\end{array}$ & $\begin{array}{l}\text { Q } \\
\text { estimation } \\
\text { (PSO) } \\
\text { (P.u) }\end{array}$ & $\begin{array}{l}\text { Abs. error } \\
\text { (WLS) }\end{array}$ & $\begin{array}{l}\text { Abs. error } \\
\text { (PSO) }\end{array}$ \\
\hline 3 & GNENW & -0.5270 & -0.5011 & -0.5163 & 0.0259 & 0.0107 \\
\hline 4 & MSL4 & -2.9250 & -3.1110 & -3.2320 & 0.1860 & 0.3070 \\
\hline 6 & KRK4 & -0.4190 & -0.3832 & -0.4017 & 0.0358 & 0.0173 \\
\hline 8 & BGS4 & -0.6940 & -0.6232 & -0.6409 & 0.0708 & 0.0531 \\
\hline 9 & BGE4 & -1.2942 & -1.2590 & -1.2884 & 0.0352 & 0.0058 \\
\hline 10 & BGN4 & -1.5322 & -1.4275 & -1.4524 & 0.1047 & 0.0798 \\
\hline 12 & AMN4 & -2.1580 & -2.2864 & -2.2327 & 0.1284 & 0.0747 \\
\hline
\end{tabular}


University of Thi-Qar Journal Vol.10 No.2 June 2015

Web Site: https://jutq.utq.edu.iq/index.php/main Email: journal@jutq.utq.edu.iq

\begin{tabular}{|l|l|l|l|l|l|l|}
\hline 13 & BGC4 & -1.9580 & -1.8783 & -1.7580 & 0.0797 & 0.2000 \\
\hline 15 & KUT4 & -1.3732 & -1.3674 & -1.3093 & 0.0058 & 0.0639 \\
\hline 16 & KUTP & 0.0298 & 0.3521 & 0.3456 & 0.3223 & 0.3158 \\
\hline 17 & HDTH & -0.7200 & -0.8924 & -0.9326 & 0.1694 & 0.2096 \\
\hline 20 & MUSG & 0.6550 & 0.5733 & 0.5982 & 0.0817 & 0.0568 \\
\hline 21 & BAB4 & -0.4041 & -0.4233 & -0.4206 & 0.0192 & 0.0165 \\
\hline 22 & GKHER & 2.0000 & 1.6170 & 1.7695 & 0.3830 & 0.2305 \\
\hline 23 & KDS4 & -3.7880 & -3.5247 & -3.5093 & 0.2633 & 0.2787 \\
\hline 25 & AMR4 & -0.5900 & -0.6547 & -0.7599 & 0.0647 & 0.1699 \\
\hline 26 & HRTP & -0.4432 & -0.4085 & -0.4215 & 0.0347 & 0.0217 \\
\hline 28 & RMULG & 0 & -0.0063 & -0.0067 & 0.0063 & 0.0067 \\
\hline
\end{tabular}

Table (5): The actual and estimated active power flow

\begin{tabular}{|c|c|c|c|c|c|c|}
\hline \multicolumn{2}{|l|}{ Bus bar } & \multirow{2}{*}{$\begin{array}{l}\text { P Flow } \\
\text { Actual } \\
\text { (P.u) }\end{array}$} & \multirow{2}{*}{$\begin{array}{l}\mathrm{P} \quad \text { Flow } \\
\text { estimation } \\
\text { (WLS) } \\
\text { (P.u) }\end{array}$} & \multirow{2}{*}{$\begin{array}{l}\mathrm{P} \quad \text { Flow } \\
\text { estimation } \\
\text { (PSO) } \\
\text { (P.u) }\end{array}$} & \multirow{2}{*}{$\begin{array}{l}\text { Abs. error } \\
\text { (WLS) }\end{array}$} & \multirow{2}{*}{$\begin{array}{l}\text { Abs. error } \\
\text { (PSO) }\end{array}$} \\
\hline From & To & & & & & \\
\hline BAJP & GNNW & 0.9800 & 1.0101 & 1.0109 & 0.0301 & 0.0309 \\
\hline BAJP & BAJG & -3.1400 & -3.1368 & -3.1368 & 0.0032 & 0.0032 \\
\hline BAJP & BGW4 & 0.3800 & 0.3176 & 0.3276 & 0.0624 & 0.0524 \\
\hline BAJP & BGW4 & 0.2853 & 0.2429 & 0.2437 & 0.0424 & 0.0416 \\
\hline BAJP & HDTH & 0.9024 & 0.7924 & 0.7935 & 0.1100 & 0.1089 \\
\hline MSL4 & $\mathrm{MMDH}$ & -1.9900 & -2.1539 & -2.1536 & 0.1639 & 0.1636 \\
\hline MSL4 & MMDH & -1.9900 & -2.1539 & -2.1536 & 0.1639 & 0.1636 \\
\hline MSL4 & BAJP & -0.9382 & -1.0365 & -1.0375 & 0.0983 & 0.0993 \\
\hline MSL4 & GNNW & 0.8983 & 0.9652 & 0.9892 & 0.0669 & 0.0909 \\
\hline KRK4 & MSL4 & 0.5932 & 0.5112 & 0.5320 & 0.0820 & 0.0612 \\
\hline KRK4 & BAJG & 0.1400 & 0.1298 & 0.1166 & 0.0102 & 0.0234 \\
\hline KRK4 & BGE4 & -0.8900 & -1.0212 & -1.0211 & 0.1312 & 0.1311 \\
\hline QIM4 & HDTH & -1.0400 & -0.9378 & -0.9404 & 0.1022 & 0.0996 \\
\hline HDTH & BGW4 & -0.3300 & $0.400-$ & -0.4005 & 0.0700 & 0.0705 \\
\hline QDSG & BGN4 & 3.4324 & 3.3066 & 3.3063 & 0.1258 & 0.1261 \\
\hline QDSG & BGN4 & 3.4324 & 3.3066 & 3.3063 & 0.1258 & 0.1261 \\
\hline BGN4 & BGW4 & 3.9600 & 3.8709 & 3.8935 & 0.0891 & 0.0665 \\
\hline BGN4 & BGE4 & -3.7032 & -3.6994 & -3.6987 & 0.0038 & 0.0045 \\
\hline BGC4 & BGW4 & 3.4700 & 3.6483 & 3.6497 & 0.1783 & 0.1797 \\
\hline BGC4 & BGS4 & -5.6400 & -5.7943 & -5.6698 & 0.1543 & 0.0298 \\
\hline AMN4 & BGE4 & 4.3500 & 4.3783 & 4.3775 & 0.0283 & 0.0275 \\
\hline AMN4 & BGS4 & -1.1800 & -1.0425 & -1.1179 & 0.1375 & 0.0621 \\
\hline AMN4 & BGS4 & -1.0181 & --0.9756 & -0.9782 & 0.0425 & 0.0399 \\
\hline AMN4 & KUTP & -2.0221 & -1.8410 & -1.9215 & 0.1811 & 0.1006 \\
\hline BGS4 & MUSP & -3.9100 & -3.0802 & -3.8424 & 0.8298 & 0.0676 \\
\hline
\end{tabular}


University of Thi-Qar Journal Vol.10 No.2 June 2015

Web Site: https://jutq.utq.edu.iq/index.php/main Email: journal@jutq.utq.edu.iq

\begin{tabular}{|l|l|l|l|l|l|l|}
\hline MUSP & BAB4 & -1.8800 & 2.0010 & -2.0020 & 3.8810 & 0.1220 \\
\hline MUSP & BAB4 & -1.8800 & -2.0010 & -2.0020 & 0.1210 & 0.1220 \\
\hline MUSG & MUSP & -2.2099 & -2.1247 & -2.1223 & 0.0852 & 0.0876 \\
\hline MUSG & BGS4 & 4.0000 & 3.8739 & 3.9878 & 0.1261 & 0.0122 \\
\hline BAB4 & GKHER & -3.2200 & -3.3762 & -3.2087 & 0.1562 & 0.0113 \\
\hline BAB4 & KDS4 & -5.4400 & -5.3256 & -5.3961 & 0.1144 & 0.0439 \\
\hline GKHER & KDS4 & 2.5200 & 2.4021 & 2.4329 & 0.1179 & 0.0871 \\
\hline NSRP & KDS4 & -1.2500 & -1.2280 & -1.2082 & 0.0220 & 0.0418 \\
\hline KUTP & KUT4 & 0.4400 & 0.4679 & 0.4552 & 0.0279 & 0.0152 \\
\hline NSRP & KUT4 & 0.2600 & 0.2439 & 0.2499 & 0.0161 & 0.0101 \\
\hline NSRP & RMLG & -1.1219 & -1.1157 & -1.1140 & 0.0062 & 0.0079 \\
\hline KUT4 & AMR4 & -1.0500 & -1.0664 & -1.0693 & 0.0164 & 0.0193 \\
\hline AMR4 & HRTP & -01.400 & -1.4721 & -1.4713 & 0.0721 & 0.0713 \\
\hline RMLG & KAZG & -1.4100 & -1.2361 & -1.2349 & 0.1739 & 0.1751 \\
\hline HRTP & KAZG & 0.4400 & 0.3792 & 0.3920 & 0.0608 & 0.0480 \\
\hline BSR4 & KAZG & 0 & 0.0929 & 0.0930 & 0.0929 & 0.0930 \\
\hline
\end{tabular}

Table (6): The actual and estimated reactive power flow

\begin{tabular}{|c|c|c|c|c|c|c|}
\hline \multicolumn{2}{|l|}{ Bus bar } & \multirow{2}{*}{$\begin{array}{l}\text { Q Flow } \\
\text { actual } \\
\text { (P.u) }\end{array}$} & \multirow{2}{*}{$\begin{array}{l}\text { Q Flow } \\
\text { estimation } \\
\text { (WLS) } \\
\text { (P.u) }\end{array}$} & \multirow{2}{*}{$\begin{array}{l}\text { Q Flow } \\
\text { estimation } \\
\text { (PSO) } \\
\text { (P.u) }\end{array}$} & \multirow{2}{*}{$\begin{array}{l}\text { Abs. error } \\
\text { (WLS) }\end{array}$} & \multirow{2}{*}{$\begin{array}{l}\text { Abs. error } \\
(\mathrm{PSO})\end{array}$} \\
\hline From & To & & & & & \\
\hline BAJP & GNNW & -0.3900 & -0.3652 & -0.3720 & 0.0248 & 0.0180 \\
\hline BAJP & BAJG & -0.4400 & -0.4452 & -0.4453 & 0.0052 & 0.0053 \\
\hline BAJP & BGW4 & -0.6400 & -0.5414 & -0.5595 & 0.0986 & 0.0805 \\
\hline BAJP & BGW4 & 0.0380 & 0.04237 & 0.04139 & 0.0044 & 0.0034 \\
\hline BAJP & HDTH & -0.2850 & -0.2732 & -0.2801 & 0.0118 & 0.0049 \\
\hline MSL4 & MMDH & -1.1320 & -1.0404 & -1.0302 & 0.0916 & 0.1018 \\
\hline MSL4 & MMDH & -1.1320 & -1.0404 & -1.0302 & 0.0916 & 0.1018 \\
\hline MSL4 & BAJP & -0.8729 & -0.8230 & -0.8463 & 0.0499 & 0.0266 \\
\hline MSL4 & GNNW & -0.0292 & -0.0219 & 0.0240 & 0.0073 & 0.0532 \\
\hline KRK4 & MSL4 & -0.9400 & -0.9304 & -0.9654 & 0.0096 & 0.0254 \\
\hline KRK4 & BAJG & -0.4000 & -0.3921 & -0.3991 & 0.0079 & 0.0008 \\
\hline KRK4 & BGE4 & 0.5800 & 0.5729 & 0.5796 & 0.0071 & 0.0004 \\
\hline QIM4 & HDTH & -0.5508 & -0.3796 & -0.4060 & 0.1712 & 0.1448 \\
\hline HDTH & BGW4 & 1.4900 & 1.3689 & 1.3984 & 0.1211 & 0.0916 \\
\hline QDSG & BGN4 & 0.8600 & 0.7700 & 0.7700 & 0.0900 & 0.0900 \\
\hline QDSG & BGN4 & 0.6800 & 0.7700 & 0.7700 & 0.0900 & 0.0900 \\
\hline BGN4 & BGW4 & -0.5000 & -0.5680 & -0.5748 & 0.0680 & 0.0748 \\
\hline BGN4 & BGE4 & 0.1600 & 0.1282 & 0.1114 & 0.0318 & 0.0486 \\
\hline BGC4 & BGW4 & -1.4400 & -1.4750 & -1.4754 & 0.0350 & 0.0354 \\
\hline BGC4 & BGS4 & -0.5000 & -0.5442 & -0.5258 & 0.0442 & 0.0258 \\
\hline
\end{tabular}


University of Thi-Qar Journal Vol.10 No.2 June 2015

Web Site: https://jutq.utq.edu.iq/index.php/main Email: journal@jutq.utq.edu.iq

\begin{tabular}{|l|l|l|l|l|l|l|}
\hline AMN4 & BGE4 & -0.7200 & -0.8806 & -0.9015 & 0.1606 & 0.1815 \\
\hline AMN4 & BGS4 & -0.6800 & -0.7147 & -0.7180 & 0.0347 & 0.0380 \\
\hline AMN4 & BGS4 & -0.6800 & -0.7147 & -0.7180 & 0.0347 & 0.0380 \\
\hline AMN4 & KUTP & -0.0600 & -0.0744 & -0.0754 & 0.0145 & 0.0155 \\
\hline BGS4 & MUSP & -0.5200 & -0.5029 & -0.5128 & 0.0171 & 0.0072 \\
\hline MUSP & BAB4 & 0.2000 & 0.1765 & 0.17880 & 0.0235 & 0.0212 \\
\hline MUSP & BAB4 & 0.2100 & 0.1765 & 0.17880 & 0.0335 & 0.0312 \\
\hline MUSG & MUSP & -0.5000 & -0.5291 & -0.5501 & 0.0291 & 0.0501 \\
\hline MUSG & BGS4 & 0.1200 & 0.1829 & 0.1928 & 0.0629 & 0.0728 \\
\hline BAB4 & GKHER & -1.5100 & -1.5892 & -1.5090 & 0.0792 & 0.0010 \\
\hline BAB4 & KDS4 & -0.6500 & -0.6054 & -0.5900 & 0.0446 & 0.0600 \\
\hline GKHER & KDS4 & 1.4000 & 1.0050 & 1.0111 & 0.3950 & 0.3889 \\
\hline NSRP & KDS4 & -0.2200 & -0.2471 & -0.2389 & 0.0271 & 0.0189 \\
\hline KUTP & KUT4 & -0.4900 & -0.6089 & -0.6199 & 0.1189 & 0.1299 \\
\hline NSRP & KUT4 & -0.6200 & -0.5892 & -0.5987 & 0.0308 & 0.0213 \\
\hline NSRP & RMLG & -0.1600 & -0.2095 & -0.2071 & 0.0495 & 0.0471 \\
\hline KUT4 & AMR4 & -0.3500 & -0.7255 & -0.7410 & 0.3755 & 0.3910 \\
\hline AMR4 & HRTP & -0.0400 & 0.0927 & 0.0780 & 0.1327 & 0.1180 \\
\hline RMLG & KAZG & 0.5000 & 0.5794 & 0.6960 & 0.0794 & 0.1960 \\
\hline HRTP & KAZG & 0.3600 & 0.5078 & 0.5220 & 0.1478 & 0.1620 \\
\hline BSR4 & KAZG & 0 & -0.0834 & -0.0904 & 0.0834 & 0.0904 \\
\hline & & & & & & \\
\hline
\end{tabular}

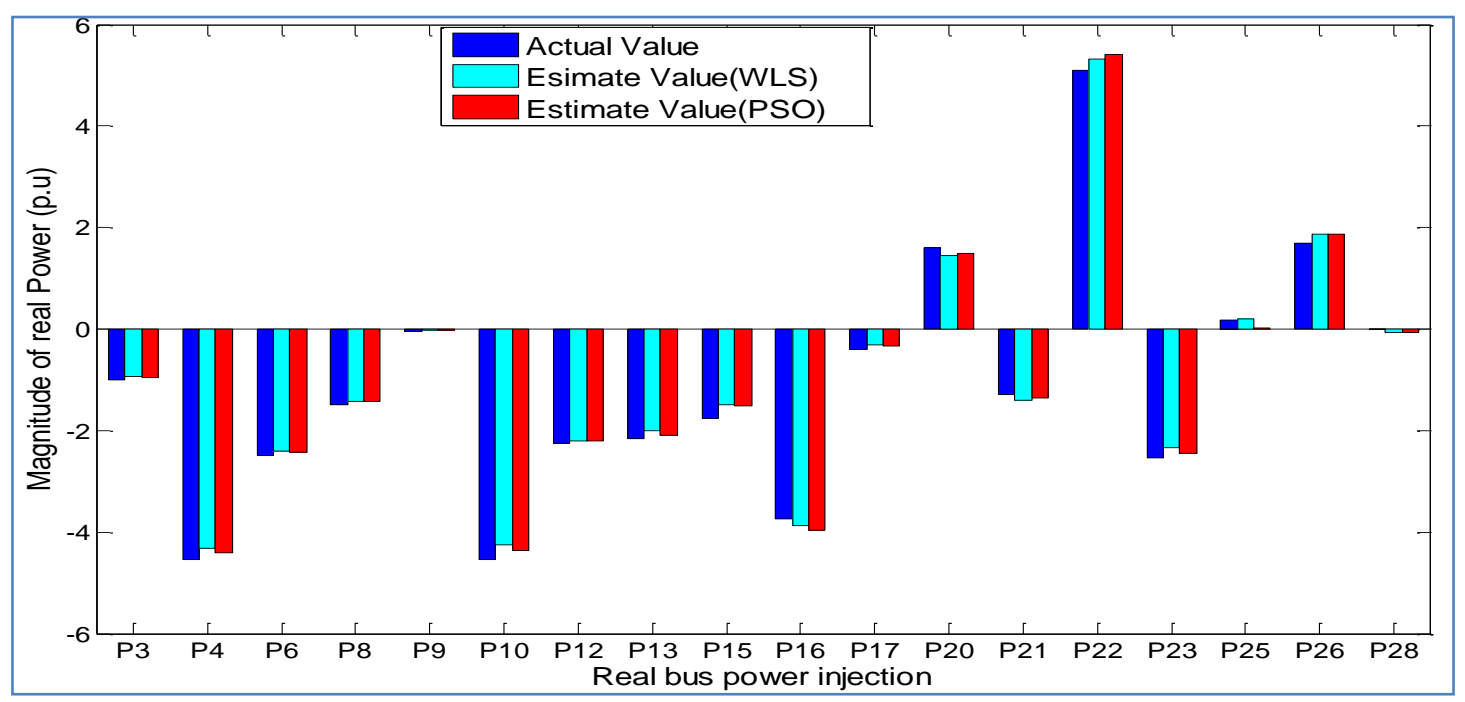

Figure (3): Comparison between actual and estimated bus real power injection

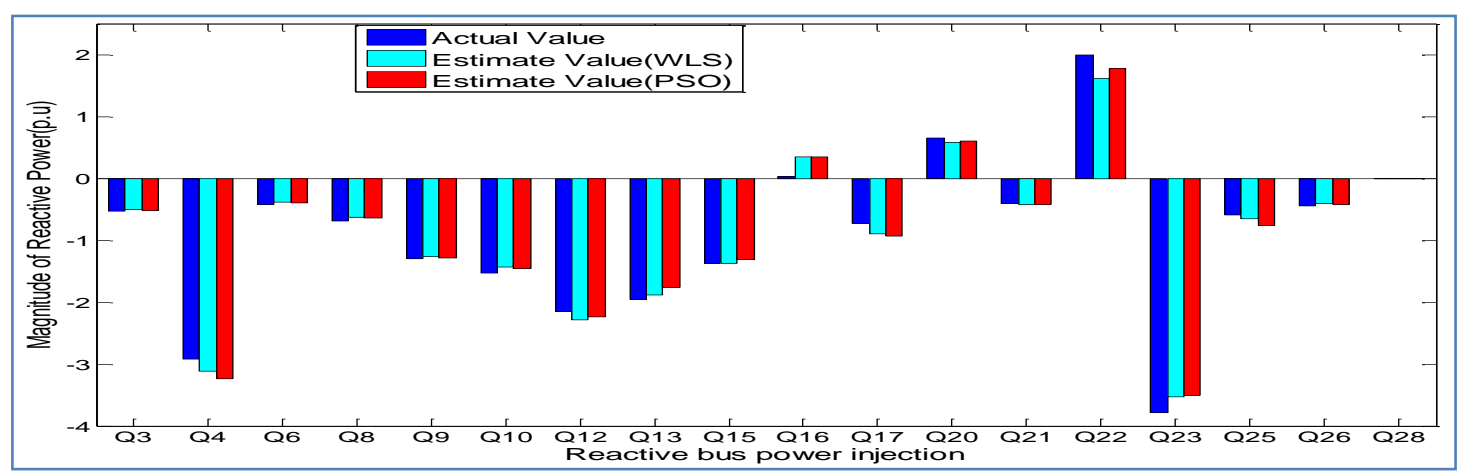


Web Site: https://jutq.utq.edu.iq/index.php/main Email: journal@jutq.utq.edu.iq

Figure (4): Comparison between actual and estimated reactive bus power injection

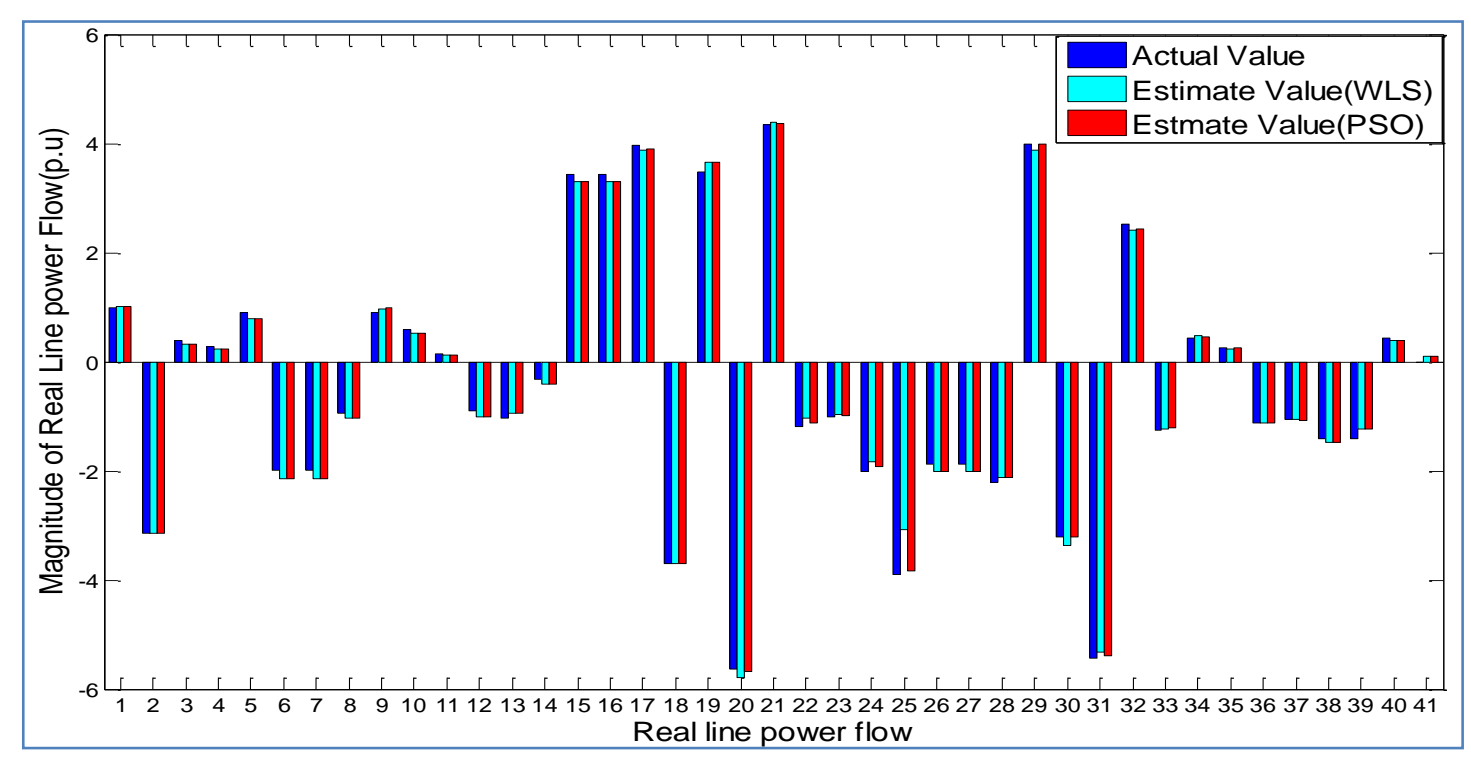

Figure (5): Comparison between actual and estimated reactive line power flow

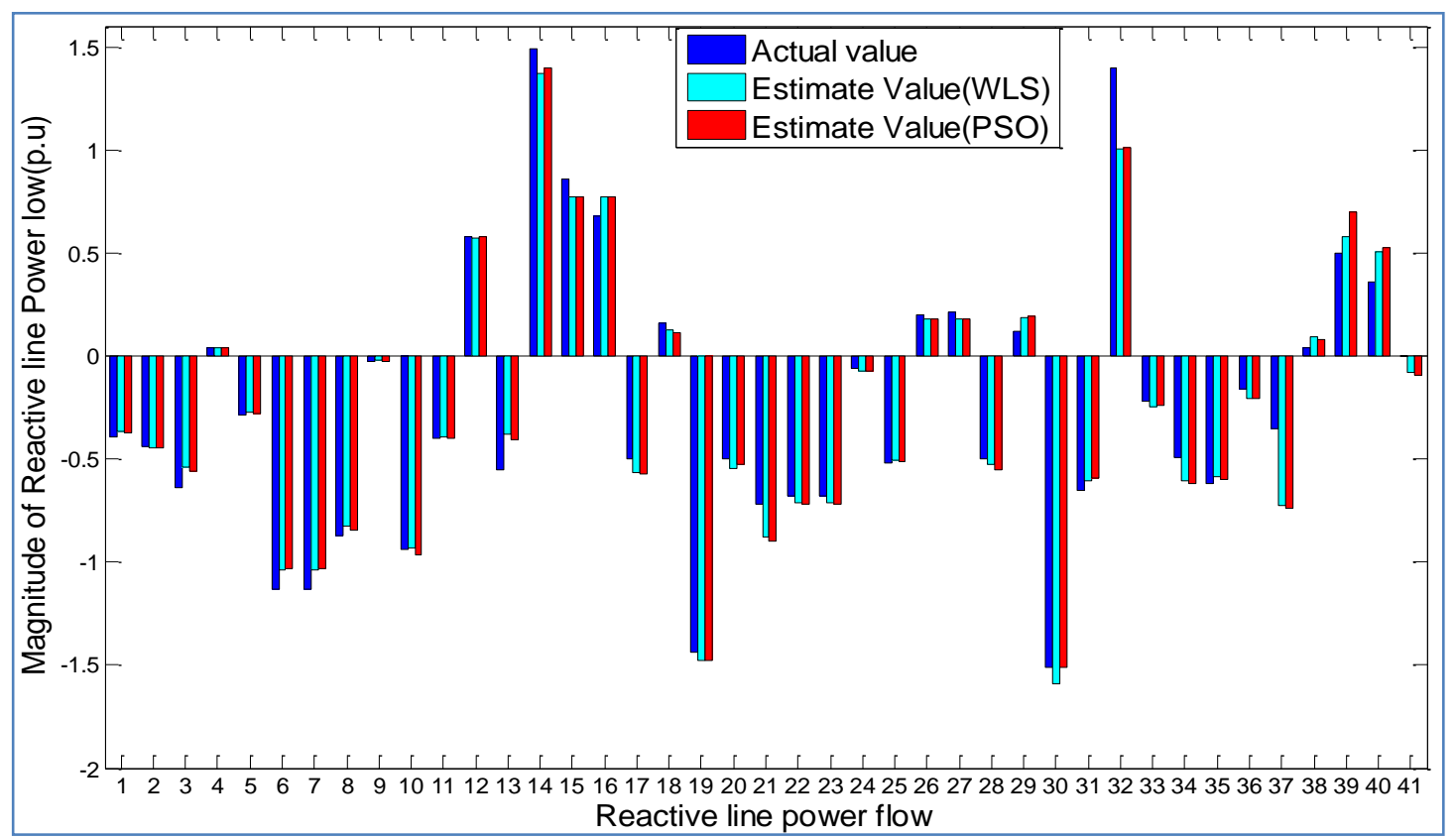

Figure (6): Comparison between actual and estimated reactive line power flow 
From the obtained results and from the analysis of the results in Tables (1 to 6), it is observe that the accuracy of (PSO) method was preferable when compared to the (WLS) method, the accuracy of the (PSO) algorithm is preferable when compared with the (WLS) algorithm on account of (MSE), from Table (1) we can see that MSE in voltage estimates in case of PSO (0.0030) is less than (0.0092) for WLS. For bus angle in Table (2) the MSE is (0.0021) for WLS and (0.0013) for PSO.

From the obtained results, it was clear that the values of the buses voltage magnitude, buses phase angle, the power injection, and line power flow, show a closer estimation to the actual value by using the two methods (WLS and PSO), but the proposed PSO estimator outperformed the conventional WLS.

\section{Conclusions}

A Particle Swarm Optimization (PSO) based approach to Power System State Estimation (PSSE) problem was presented in this work. The obtained results using the proposed approach were compared with the conventional method the Weighted Least Square method (WLS). By summarizing all results of the estimated values in the two methods, it can be seen that they are very close to the actual case values and differ only by a few degrees in both methods when no bad data are presented and the PSO is more efficient and accurate than Weight Least Square (WLS) method, therefore, the Particle Swarm Optimization (PSO) may consider as a successful technique in Power System State Estimation problem, since it has an effective and robust performance for solving state estimation through its ability to detect and identify bad data location correctly by identifying the largest normalized residual.

\section{References}

[1] A. J. Wood and B. F. Wollenberg "Power Generation Operation and Control" $2^{\text {nd }}$ Ed. New York, N. Y: Wiley, 1996.

[2] F. C. Schweepe, J. Wilders and D. B. Rom, "Power System Static State Estimation. Part I, II, and III", IEEE Transaction on power Application and Systems, Vol. PAS - 89, No. 1, pp. 120 - 135, January, 1970.

[3] Kai Yin Kenny Poon, "External Data Exchange Issues for State Estimation in Power Systems", Ph.D. Thesis Washington State University, May, 2012.

[4] V. Gomathi, V. Ramachandran, C.V Kumar, "Simulation and State Estimation of Power System with Interline Power Flow Controller", Universites Power Engineering Conference (UPEC), $31^{\text {st }}$ September, 2010.

[5] Hee-Myung Jeong, June Ho Park and Hwa-Seok Lee, "Multiple Bad Data Identification using Binary Particle Swarm Optimization", IEEE Journal of International Council on Electrical Engineering Vol. 1, No. 3, pp. 269-273, 2011.

[6] Yuan Liao, Jiaxiong Chen, "State Estimation and Power Flow Analysis of Power Systems", IEEE Journal of Computers, Vol. 7, No. 3, March, 2012.

[7] Efthymios Manitsas, Ravindra Singh, Bikash C. Pal, and Goran Strbac "Distribution System State Estimation using an Artificial Neural Network 
Web Site: https://jutq.utq.edu.iq/index.php/main Email: journal@jutq.utq.edu.iq

Approach for Pseudo Measurement Modeling”, IEEE Transactions on power systems, Vol. 27, No. 4, November, 2012.

[8] H. M. Rosli, H. Mokhlis, A. H. A. Bakar, "Optimal Measurement Placement using PSO for State Estimation", IEEE International Conference on Power and Energy, Malaysia, December 2012.

[9] D. H. Tungadio, B. P Numbi, M. W. Siti, J. A. Jordaan, "Weighted Least Squares and Iteratively Reweighted Least Squares Comparison using Particle Swarm Optimization Algorithm in Solving Power System State Estimation", Proceeding IEEE, South Africa, 2013

[10] A. Abur, A. Gomez Exposito, "Power System State Estimation Theory and Implementation" Marcel Dekker, Inc., 2004.

[11] J. J. Grainger, W.D. Stevenson, "Power System Analysis", McGraw-Hill, New York, 1994.

[12] B. S. Rao Singiresu, "Engineering Optimization Theory and Practice", John Wiley \& Sons, 2009.

[13] J. Kennedy, "The Particle Swarm: Social adaptation of knowledge", proc. IEEE Intl. Conf. Evol. Comput. ICEC, Indianapolis, USA, 1997.

[14] Shigenori Naka, Takamu Genji, Toshiki Yura, and Yoshikazu Fukuyama, "Practical Distribution State Estimation using Hybrid Particle Swarm Optimization", Proc. Of IEEE Power Engineering, Society Winter Meeting, Jan. 28 - February, 2001.

[15] Hee Myung Jeong and June Ho Park, "Power System State Estimation Using Parallel Particle Swarm Optimization based on PC Cluster System", The International Conference on Electrical Engineering, Vol. O-082, July, 2008. 


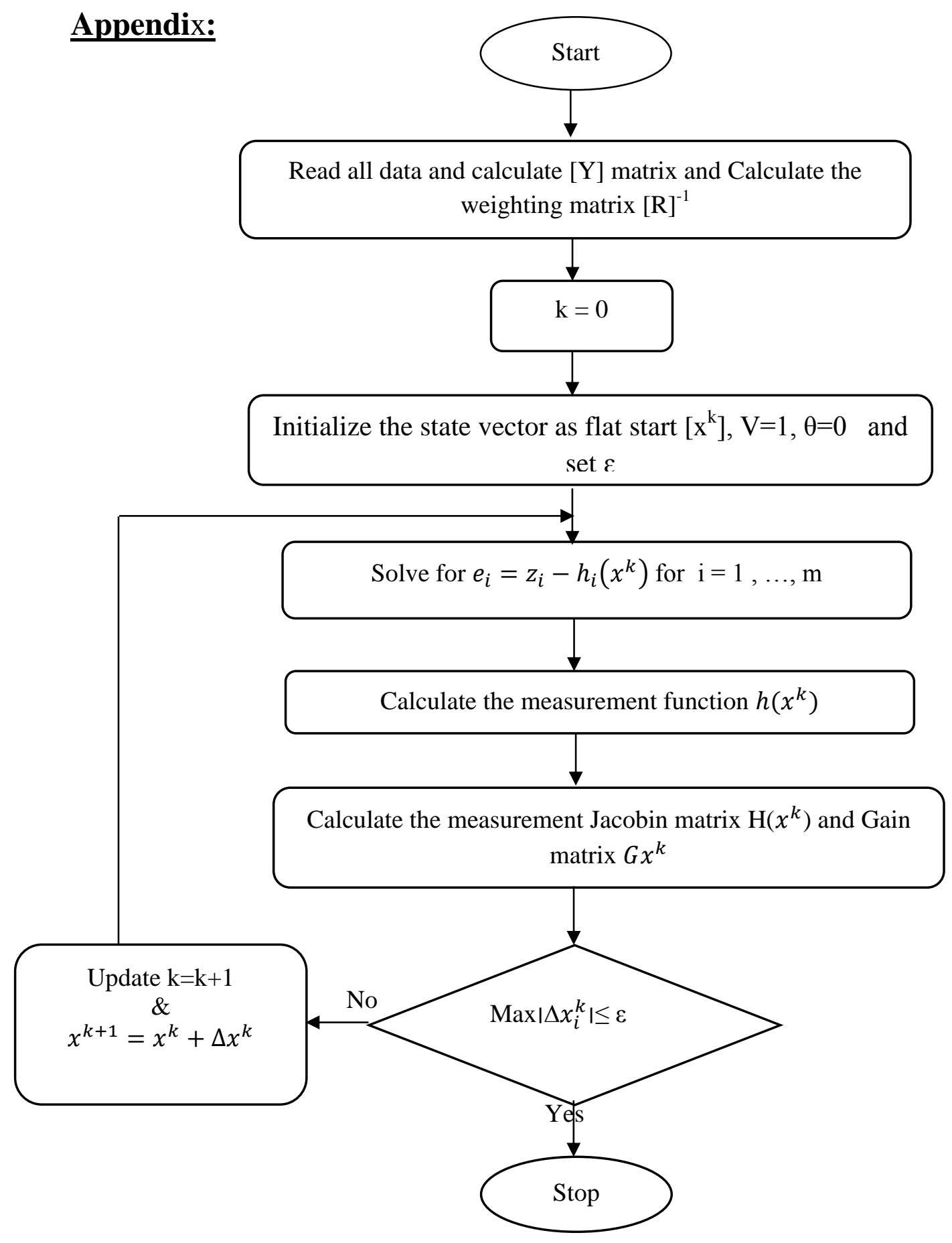

Figure (A): Flowchart Weighted Least Square (WLS) technique

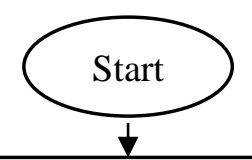

Read: latest measurements vector [z]. variance $\delta^{2}$. Line data of the system, number of buses $(\mathrm{N})$ and number of measurements (m).

Calculated $[\mathrm{Y}]$ matrix and the weighting matrix $[\mathrm{R}]$ 


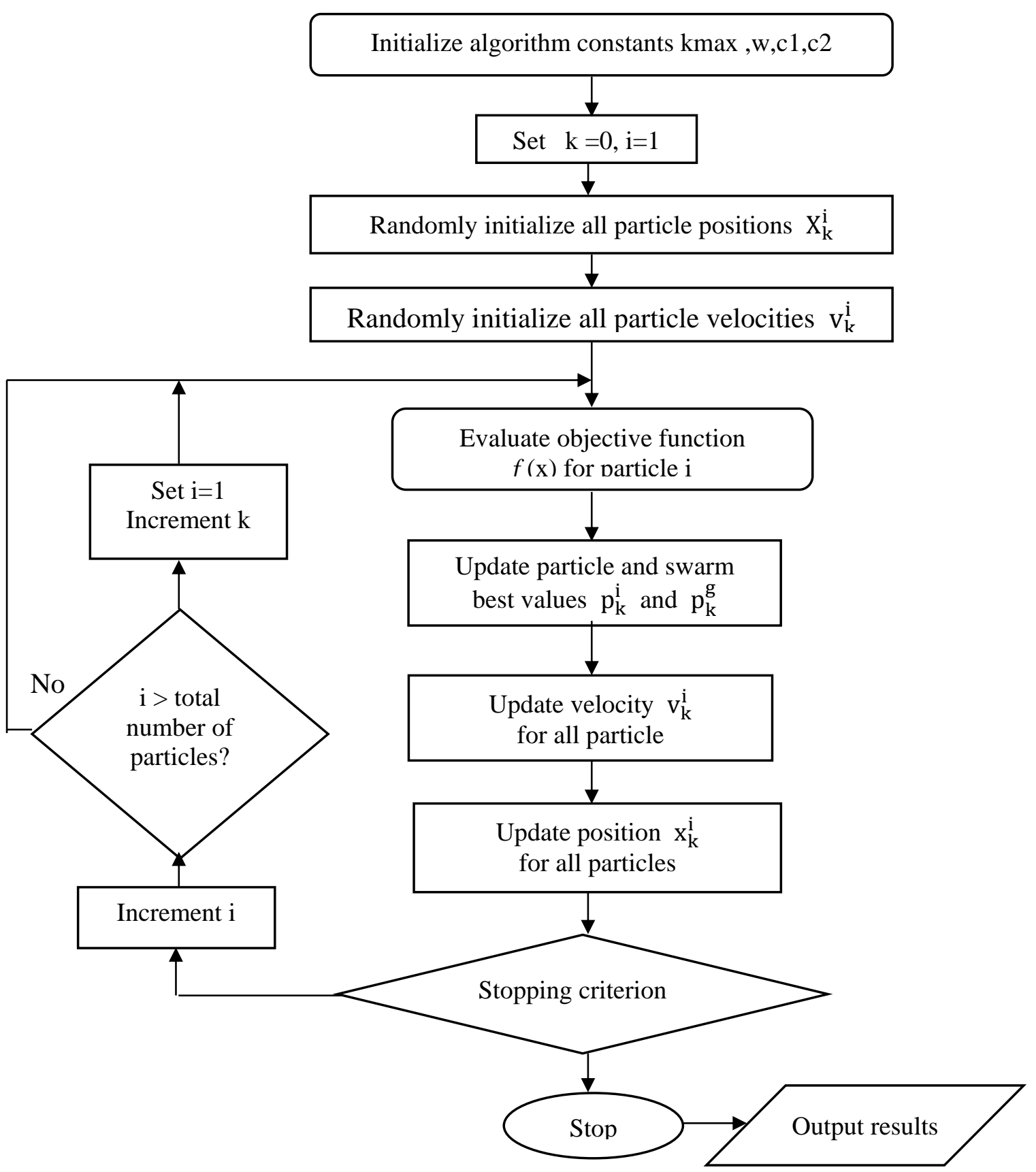

Figure (B) Flowchart of state estimation by use Particle Swarm Optimization (PSO) 